УДК 619:616.995.1:636.2

(C) 2012

Клименко О. С., кандидат ветеринарних наук,

Клименко І. І., Мазуріка В. В., Юрченко Ю. В., студенти IV курсу ФВМ

Полтавська державна аграрна академія

\title{
ГЕЛЬМІНТОЗИ ВЕЛИКОЇ РОГАТОЇ ХУДОБИ ОДНООСІБНИХ ГОСПОДАРСТВ ПОЛТАВСЬКОЇ ОБЛАСТІ
}

\section{Рецензент - доктор ветеринарних наук В. О. Свстаф'єва}

Наведено результати копроовоскопічних досліджень ВРХ одноосібних господарств Полтавської області. Дослідженнями встановлено паразитування фасиіол, дикрочелій, парамфістом та стронгілят органів травлення у вигляді моно- та поліінвазій. Екстенсивність гельмінтозної інвазії у тварин коливається в межах 6,25-35,7\%, а інтенсивність -

0,3-4,3 екземплярів яєць в 1 грамі. Високий ступінь інвазії тварин підтверджує актуальність зазначеної проблеми, тому перспективою подальших досліджень є обов'язкова розробка та впровадження у приватних господарствах заходів боротьби з гельмінтозами.

Ключові слова: гельмінтози, екстенсивність, інтенсивність, велика рогата худоба (ВРX), одноосібні господарства.

Постановка проблеми. Продовольчий ринок усього світу з кожним роком вимагає все більше якісних і безпечних продуктів харчування, до того ж левова частка припадає на продукцію тваринництва. В Україні до внутрішніх проблем, що перешкоджають збільшенню обсягів виробництва й нарощування поголів'я, належать інвазійні хвороби. Попри велику кількість досліджень і рекомендацій щодо лікування й профілактики паразитарних захворювань, ураженість ВРХ гельмінтами у господарствах України залишається досить високою, що супроводжується зниженням продуктивності тварин i, як наслідок, збитковістю галузі. Наразі назріло питання контролю паразитозів великої рогатої худоби приватних господарств. На сьогодні кількість худоби в цих господарствах перевищує таку ж у колективних підприємствах [7]. Тому питання моніторингових досліджень паразитарних хвороб великої рогатої худоби в одноосібних господарствах залишається актуальним.

Аналіз останніх досліджень і публікацій, у яких започатковано розв'язання проблеми. Дослідники 3 різних регіонів України зазначають, що з-поміж паразитів великої рогатої худоби домінуть фасціоли, парамфістоми та стронгіліди.
Чисельні повідомлення науковців і практичних лікарів ветмедицини свідчать, що більшість регіонів країни залишаються неблагополучними стосовно трематодозів жуйних тварин. Так, в окремих господарствах Полісся екстенсивність фасціольозної інвазії сягає 90 \%, а на Слобожанщині цей показник коливається в межах 70-90 \%. Одночасне паразитування фасціол і дикроцелій у зазначених регіонах діагностується в $18,1-25,5 \%$, а фасціол і парамфістом - у 75-80 \% тварин [1-4]. У центральній частині України досить часто реєструється сетаріозно-дикроцеліозно-стронгілятозна мікстінвазія великої рогатої худоби, а в окремих господарствах екстенсивність стронгілятозної інвазії досягає $100 \%$ [2; 5; 6].

Оскільки зазначені дослідження стосуються колективних господарств, метою нашої роботи було вивчити гельмінтофауну великої рогатої худоби одноосібних господарств у Полтавській області.

Матеріали і методи досліджень. Дослідження проводили в одноосібних господарствах Гадяцького та Миргородського районів Полтавщини, а також у лабораторії кафедри паразитології та ветсанекспертизи Полтавської державної аграрної академії.

Із метою діагностики гельмінтозів у тварин відбирали проби фекалій і досліджували їх стандартизованим методом послідовних промивань та флотаційним методом за КотельниковимХреновим.

Результати досліджень. Результатами копроовоскопічних досліджень встановлено значне поширення гельмінтозів жуйних тварин в одноосібних господарствах Полтавської області. В пробах фекалій великої рогатої худоби виявляли яйця парамфістом, дикроцелій, фасціол та стронгілят органів травлення (рис. 1-4).

У ході дослідження 42 голів великої рогатої худоби одноосібних господарств Миргородського району у 15 голів було виявлено паразитування парамфістом, а в 12 - стронгілят органів травлення (табл. 1). 
ВЕТЕРИНАРНА МЕДИЦИНА

\section{1. Гельмінтози великоӥ рогатої худоби господарств Миргородського району}

\begin{tabular}{|c|c|c|c|c|}
\hline Захворювання & $\begin{array}{c}\text { Досліджено, } \\
\text { гол. }\end{array}$ & $\begin{array}{c}\text { Виявлено хворих, } \\
\text { гол. }\end{array}$ & $\begin{array}{c}\text { Інтенсивність } \\
\text { інвазії, екз./ 1 г }\end{array}$ & $\begin{array}{c}\text { Екстенсивність } \\
\text { інвазії, \% }\end{array}$ \\
\cline { 1 - 4 } Парамфістомоз & \multirow{2}{*}{42} & 15 & 4,3 & 35,7 \\
\cline { 1 - 5 } Стронгілятози & & 12 & 3,0 & 28,6 \\
\hline
\end{tabular}

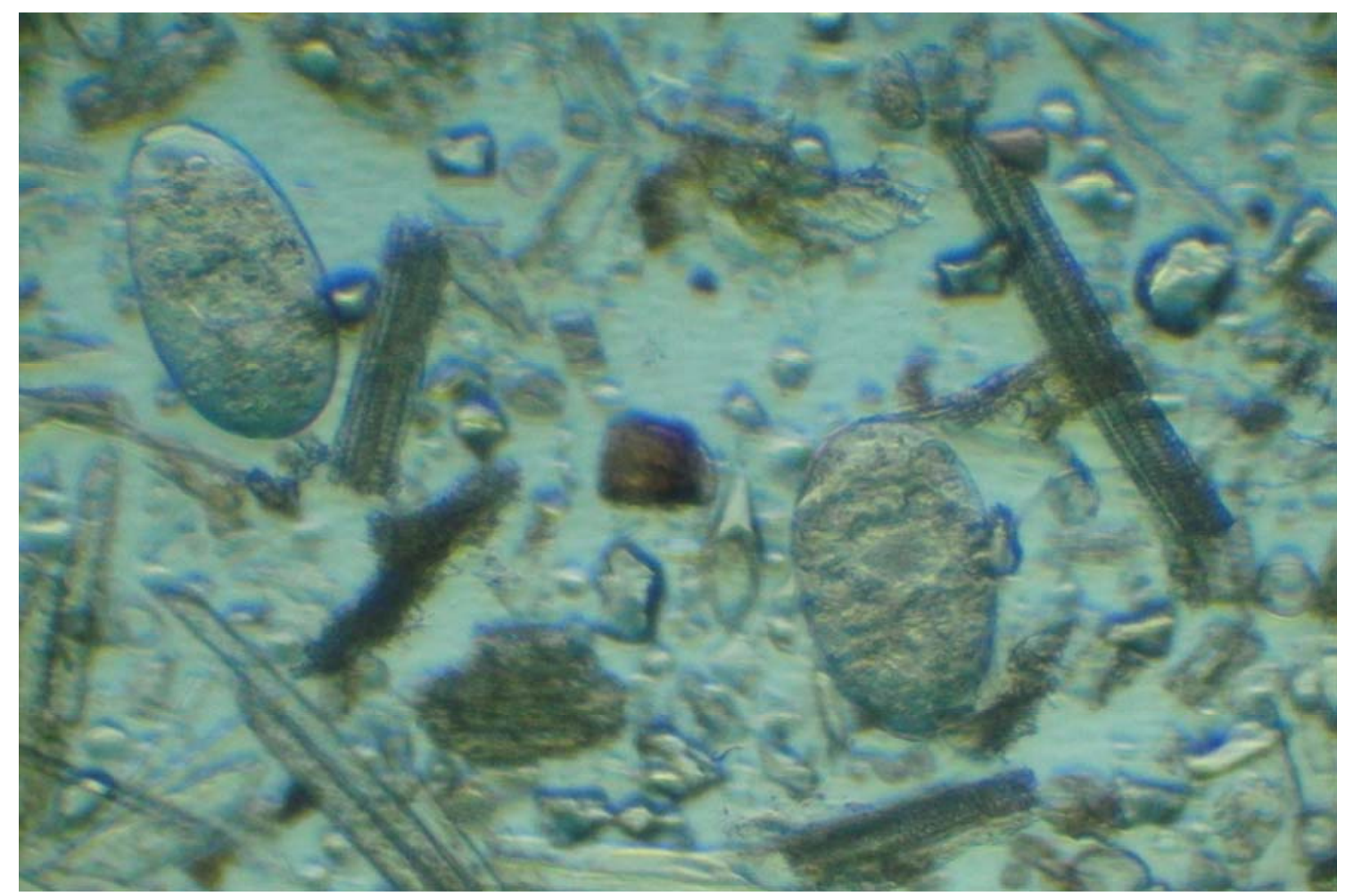

Рис. 1. Яйця парамфістом (х400)

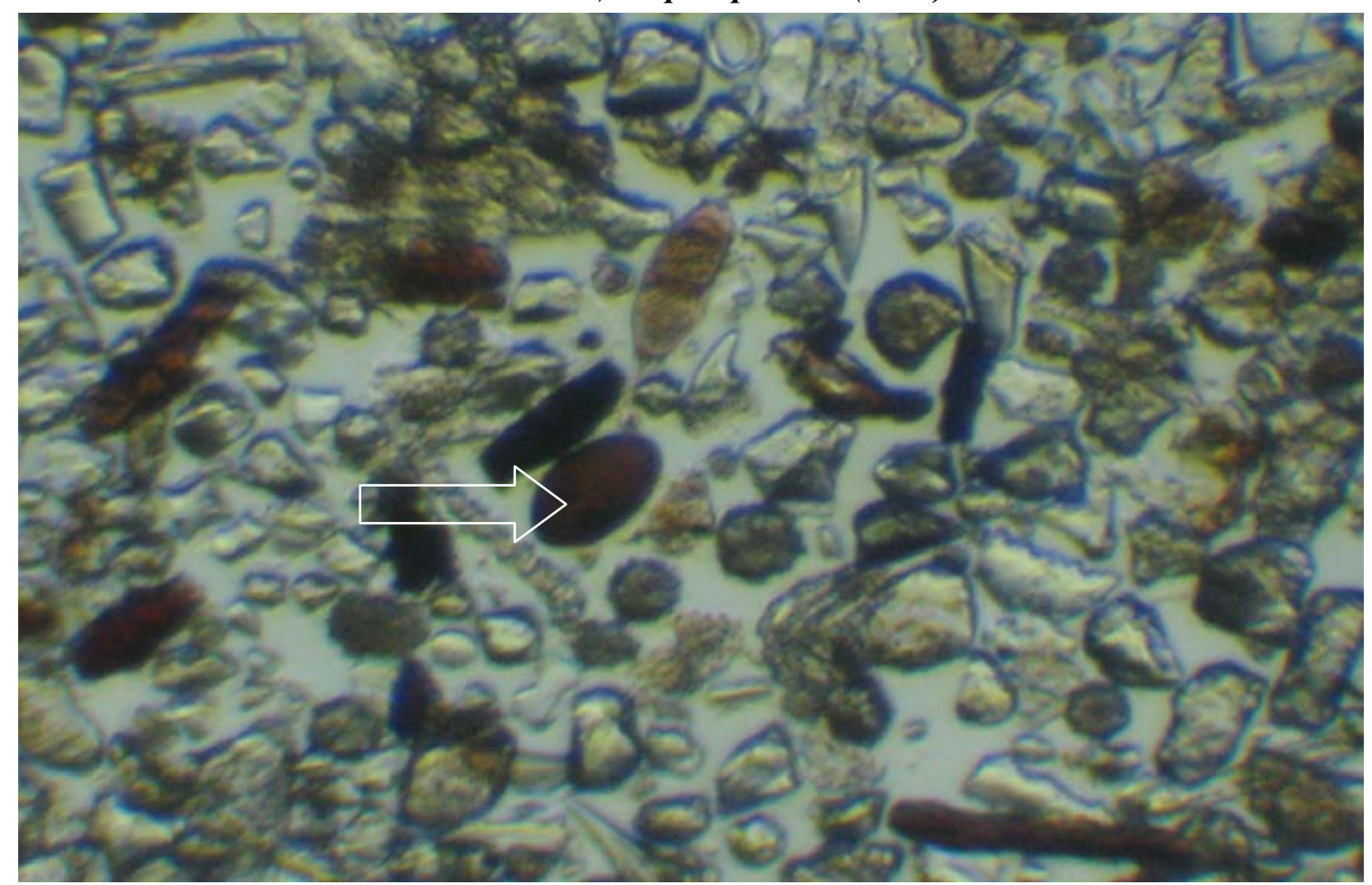

Рис. 2. Яйце дикроцелій (х400) 


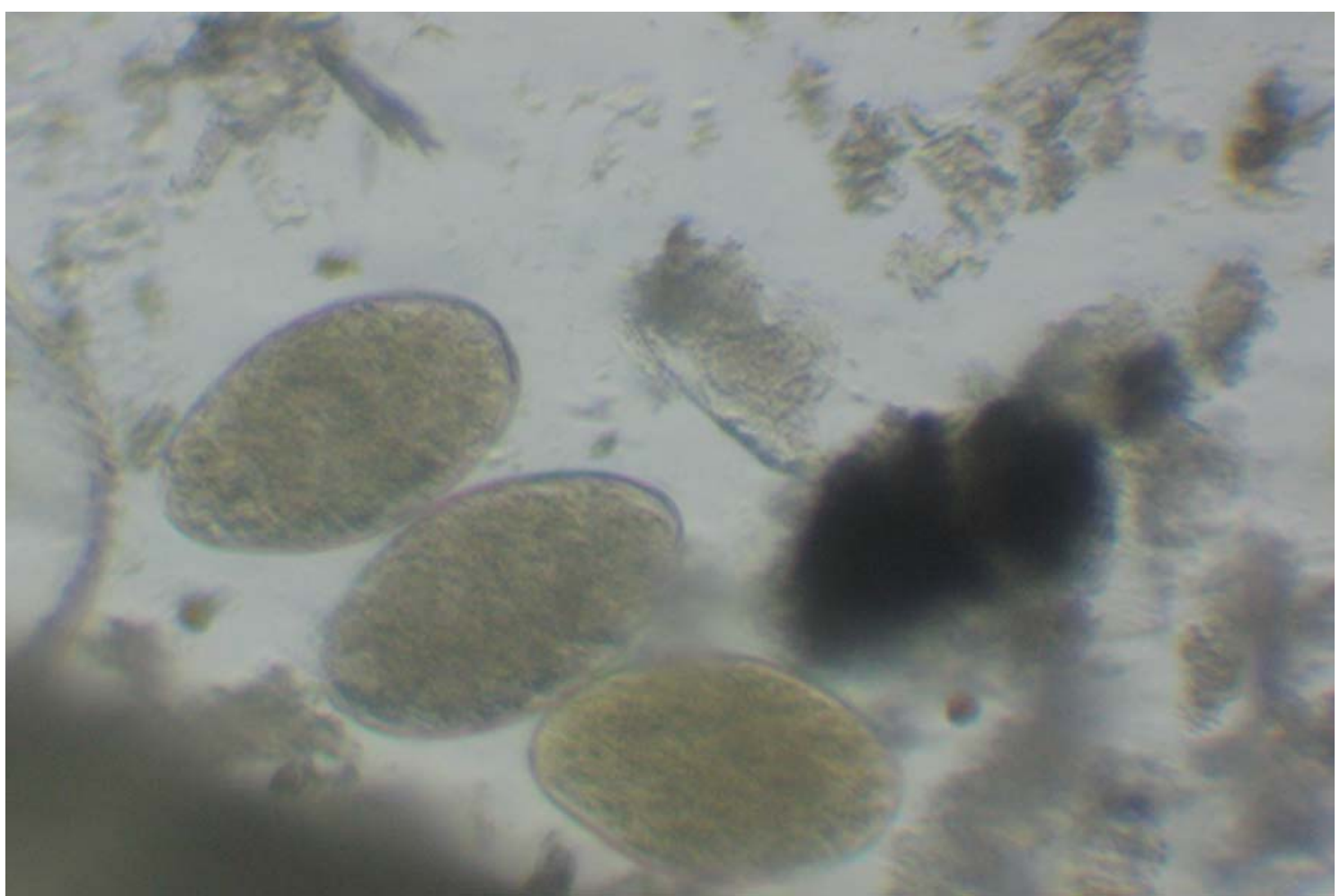

Рис. 3. Яйця фасціол (х400)

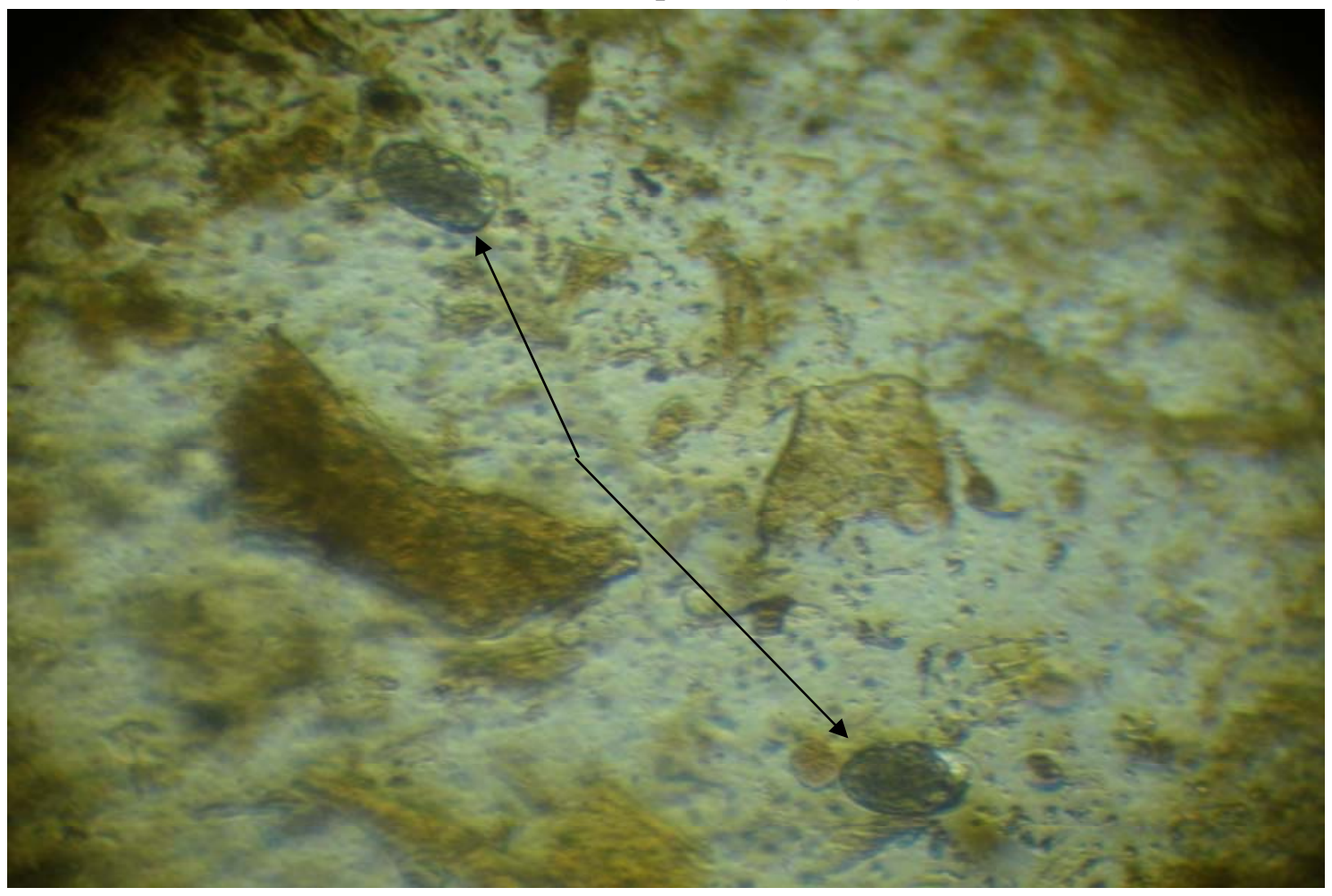

Рис. 4. Яйця стронгілідного типу (х135)

Екстенсивність трематодозної інвазії становила 35,7 \% при інтенсивності - 4,3 екз. яєць /1 г. Ураженість кишковими стронгілятами була нижчою - 28,6 \% та 3,0 екземплярів у 1 грамі.

Паразитофауна жуйних тварин Гадяцького району представлена фасціолами, дикроцеліями та кишковими стронгілідами (табл. 2). Екстенсивність фасціольозної інвазії становила 20,83 \%, дикроцеліозної - 6,25\%, стронгілятозної - 27,08 \%, при II, відповідно, 2,8; 2,3 та 0,3 екз. яєць в 1 г фекалій. 
2. Гельмінтози великої рогатої худоби господарств Гадяцького району

\begin{tabular}{|c|c|c|c|c|}
\hline Захворювання & Досліджено, гол. & $\begin{array}{c}\text { Виявлено хворих, } \\
\text { гол. }\end{array}$ & $\begin{array}{c}\text { Інтенсивність } \\
\text { iнвазії, екз./ } 1 \text { г }\end{array}$ & $\begin{array}{c}\text { Екстенсивність } \\
\text { інвазії, \% }\end{array}$ \\
\hline Фасціольоз & \multirow{3}{*}{48} & 10 & 2,8 & 20,83 \\
\hline Стронгілятози & & 13 & 2,3 & 27,08 \\
\hline Дикроцеліоз & & 3 & 0,3 & 6,25 \\
\hline
\end{tabular}

Отримані дані свідчать, що у великої рогатої худоби одноосібних господарств Гадяцького та Миргородського районів Полтавщини паразитують гельмінти у вигляді моно- та поліінвазій. Причиною цього може бути неконтрольована дегельмінтизація за відсутності діагностичних досліджень. Результати досліджень підтвердили актуальність зазначеної проблеми у господарствах відповідної форми власності.

Тому подальші дослідження слід спрямувати на розробку заходів боротьби й профілактики 3

\section{БІБЛІОГРАФІЯ}

1. Дахно І., Дахно Г., Кручиненко О., Березовський $A$. Терапевтична та економічна ефективність комбітрему на ранній стадії фасціольозної інвазії корів // Ветеринарна медицина України. 2004. - №8. - C. 16-17.

2. Дахно І. С., Клименко О. С. Паразитози великої рогатої худоби // Науковий вісник НАУ. 2006. - Вип. 98. - С. 49-52.

3. Дахно I. С. Протифасціольозні заходи у тваринництких господарствах молочного напрямку

// Вісник СНАУ. - Суми, 2010. - №3 (26). C. 41-45.

4. Динька А. Профілактика - запорука здоров'я // Ветеринарна медицина України. - 2004. - №8. C. 20 . гельмінтозами жуйних тварин і їх масове впровадження в одноосібних господарствах області.

Висновки. В одноосібних господарствах Полтавської області діагностуються фасціольоз, дикроцеліоз, парамфістомоз та стронгілятози органів травлення у вигляді моно- та поліінвазій. Екстенсивність фасціольозної інвазії становить $20,83 \%$, парамфістомозної - 35,7 \%, дикроцеліозної $-6,25 \%$, а стронгілятозної органів травлення $-27,77 \%$, при інтенсивності: 2,$8 ; 4,3 ; 0,3$ та 2,6 екз. яєць в 1 грамі.

5. Пономаренко В. Я. До питання про стронгілятози травного тракту великої рогатої худоби (епізоотологічний моніторинг, ефективність препаратів) // Тези доповідей XII конф. Українського наук. тов-ва паразитологів. Севастополь. - 10-12 вересня 2002. - К., 2002. - С. 90.

6. Темний М. В., Приходько Ю. О. Виживання яєць і личинок стронгілят травного каналу в розчинах антигельмінтиків як фактор появи резистентності // Ветеринарна медицина України. 2010. - №4. - C. 12-13.

7. Ткач Ю. А. До проблем оздоровлення тваринництва від гельмінтозів // Ветеринарна медицина України. - 2009. - №6. - С. 18-19. 